Recommended by Doctor of Pharmacy, professor D. I. Dmitrievsky

UDC 615.246.4/.6 (477)

DOI: $10.24959 /$ nphj. 17.2145

T. Ivko, T. Germanyuk, L. Bobritskaya*

National Pirogov Memorial Medical University

* National University of Pharmacy

\title{
The study of the Ukrainian pharmaceutical market of laxatives
}

Constipation is one of the most common reasons for visiting a doctor in the world. In different countries every third or fourth adult has constipation continuously or periodically. Laxatives (L) are OTC-drugs. Therefore, to simplify the choice of a laxative by patients, pharmacists and doctors the study of the pharmaceutical market of $L$ is of current interest.

Aim. To analyze the pharmaceutical market of laxatives in Ukraine.

Material and methods. Data of ATC/DDD-indexes of the WHO Center on methodology of statistical studies of drugs, doses for $L$ recommended by the manufacturer, data on the average retail price of medicines in Ukraine in August 2016 were used in the study. The methods of research were frequency analysis and ATC/DDD-methodology.

Results and discussion. As the result of the structural analysis of the ATC classification and the presence of $L$ at the pharmaceutical market of Ukraine it was found that the following drugs of group A06A were available to treat constipation: softeners (emollients), contact L, bulk-forming L, osmotically acting L, $L$ in enemas and other drugs. The frequency analysis showed that there were 18 INN and 76 TN of $L$ at the pharmaceutical market of Ukraine in 2016; among them domestic drugs were $55 \%$, and foreign - $45 \%$. Laxatives were supplied in Ukraine by such manufacturing countries as Portugal, Italy, Spain, Poland, France, Germany, India, Netherlands, Bulgaria, Latvia, Russian Federation and United Kingdom. The cost of the defined daily dose (DDD) for softeners (Vaseline oil) ranged from 2.94 to $3.39 \mathrm{UAH}$. The cost of DDD for contact $L$ was from 0.60 to $3.90 \mathrm{UAH}$ : for bisacodyl - from 0.60 to $2.82 \mathrm{UAH}$, for castor oil $-2.50-$ 5.13 UAH, for senna glycosides - 0.84-3.20 UAH, for sodium picosulfate - 1.35-3.90 UAH, for combination of sodium picosulfate with a dry extract of senna leaves - 1.34-1.55 UAH. The cost of DDD of bulk-forming $L$ ranged from 1.75 to $129.03 \mathrm{UAH}$ : for $\mathrm{L}$ with Plantago ovata seeds ranged from 3.58 to $28.92 \mathrm{UAH}$, for laminaria $-1.75-1.97 \mathrm{UAH}$. The cost of DDD for osmotically acting $L$ varied from 2.51 to $112.59 \mathrm{UAH}$ : for magnesium sulfate $-2.15-2.51 \mathrm{UAH}$., and the cost for combination of inorganic salts - $112.59 \mathrm{UAH}$, for macrogol - 51.01 UAH, for lactulose - 3.75-18.74 UAH, for combinations with macrogol - 54,88-127,32 UAH. The cost of DDD for L in enemas varied from 33.39 to 129.03 UAH. The cost of DDD for other drugs for treatment of constipation was from 1.37 to $48.15 \mathrm{UAH}$ : for glycerol - 3.44-36.49 UAH, for prucalopride - 31.72-48.15 UAH, for others - 1.37-1.49 UAH.

Conclusions. In 2016 there were 18 INN and 76 TN of laxatives at the pharmaceutical market of Ukraine; drugs of domestic manufacture prevailed, the ratio between domestic and foreign drugs was $1.2: 1$. The cost of DDD for L in the context of the minimum and maximum cost of generics ranged from 0.60 to $129.03 \mathrm{UAH}$.

Key words: constipation; laxatives; cost of DDD; ATC/DDD methodology

Т. І. Івко, Т. А. Германюк, Л. О. Бобрицька

\section{Дослідження українського фармацевтичного ринку послаблюючих засобів}

На теперішній час закреп є однією з найпоширеніших причин звернення до лікаря у всьому світі. У різних країнах на закрепи постійно або періодично страждає кожна третя-четверта доросла людина. Лікарські засоби (Л3) для лікування закрепів відносяться до ОТС препаратів, тому актуальним є дослідження фрармацевтичного ринку послаблюючих засобів (ПЗ), щоб спростити вибір цих лікарських засобів лікарями, провізорами і хворими.

Мета роботи - аналіз фармацевтичного ринку послаблюючих засобів в Україні.

Матеріали та методи. Матеріалом дослідження стали дані ATC/DDD-індексів Центру BOОЗ з методології статистичних досліджень ЛЗ, дані рекомендованих виробниками середніх добових доз (defined daily dose, DDD) послаблюючих засобів, середньозважена роздрібна вартість ЛЗ в Україні станом на серпень 2016 р. Методи дослідження: частотний аналіз, ATC/DDD-методологія.

Результати та їх обговорення. В результаті проведеного структурного аналізу АТС-класифікації ПЗ та присутності ПЗ на фармацевтичному ринку України встановлено наявність групи А06А - ЛЗ, що застосовуються для лікування закрепів: ПЗ, що розм'якшують калові маси, контактні ПЗ, ПЗ, що формують об'єм, осмотичні ПЗ, ПЗ в клізмах та інші ПЗ. Частотний аналіз показав, що на фрармацевтичному ринку України 2016 р. ПЗ були представлені 18 міжнародними непатентованими назвами (МНH), 76 торговими назвами (ТН), з них вітчизняні ПЗ на фрармацевтичному ринку склали 55 \%, іноземні - 45 \%. На територію України ПЗ постачають іноземні виробники таких країн, як Португалія, Італія, Іспанія, Польща, Франція, Німеччина, Індія, Нідерланди, Болгарія, Латвія, Російська Федерація та Велика Британія. Вартість DDD для ПЗ, що розм'якшують калові маси (вазелінова олія), коливалась від 2,94 до 3,39 грн. Вартість DDD для контактних П3 коливалась від 0,60 до 3,90 грн: для ПЗ з МНН бісакодил - від 0,60 до 2,82 грн, олія Рицинова - 2,50-5,13 грн, глікозиди Сени - 0,84-3,20 грн, натрію пікосульфат - 1,35-3,90 грн, комбінація натрію пікосульфрату з сухим екстрактом листя Сени - 1,34-1,55 грн. Вартість DDD для П3, що формують об'єм, коливалась від 1,75 до 28,92 грн: ПЗ з насіння Подорожника яйцеподібного - від 3,58 до 28,92 грн, Ламінарії - 1,75-1,97 грн. Вартість DDD для осмотичних ПЗ коливалась від 2,51 
до 112,59 грн: з МHН магнію сульфат - від 2,15 до 2,51 грн, вартість DDD для П3 з МНH лактулоза коливалась від 3,75 до 18,74 грн, макроголу - 54,88-127,32 грн, а вартість комбінації неорганічних солей склала 112,59 грн, макроголу - 51,01 грн. Вартість DDD для П3 в клізмах коливалась від 33,39 до 129,03 грн. Вартість DDD для інших ПЗ коливалась від 1,37 до 48,15 грн: гліцеролу - 3,44-36,49 грн, прукалоприду - 31,72-48,15 грн та різних ПЗ - 1,37-1,49 грн.

Висновки. На фрармацевтичному ринку послаблюючих засобів в Україні представлено 18 МHН та 76 TH; переважали препарати вітчизняного виробництва у співвідношенні 1,2 : 1; вартість DDD в розрізі мінімальної та максимальної вартості генериків для всіх, представлених у цьому дослідженні ПЗ, коливалась від 0,60 до 129,03 грн.

Ключові слова: закреп; послаблюючі лікарські засоби; вартість середньої добової дози; ATC/DDD-методологія

\section{Т. И. Ивко, Т. А. Германюк, Л. А. Бобрицкая}

\section{Исследование украинского фрармацевтического рынка слабительных средств}

На сегодняшний день запор является одной из самых распространенных причин обращения к врачу во всем мире. В разных странах запорами постоянно или периодически страдает каждый третий-четвертый взрослый человек. Лекарственные средства (ЛС) для лечения запоров относятся к ОТС препаратам, поэтому актуальным является исследование фармацевтического рынка слабительных средств для упрощения выбора этих ЛС врачами, провизорами и больными.

Цель работы - анализ фармацевтического рынка слабительных средств в Украине.

Материалы и методы. Материалом исследования стали данные ATC/DDD-индексов Центра BO3 по методологии статистических исследований ЛС, данные рекомендованных производителями средних суточных доз (defined daily dose, DDD) слабительных средств (CC), средневзвешенная розничная стоимость ЛС в Украине в августе 2016 г. Методы исследования: частотный анализ, ATC/DDD-методология.

Результаты и их обсуждение. В результате проведенного структурного анализа АТС-классификации и присутствия СС на фрармацевтическом рынке Украины установлено наличие группы А06А - ЛС, применяемые для лечения запоров: СС, которые размягчают каловые массы, контактные СС, СС, фрормирующие объем, осмотические СС, СС в клизмах и другие СС. Частотный анализ показал, что на фармацевтическом рынке Украины 2016 г. СС были представлены 18 международными непатентованными названиями (МНH) и 76 торговыми названиями (ТН), из них отечественные СС составили $55 \%$, иностранные - $45 \%$. На территорию Украины поставляют СС иностранные производители таких стран, как Португалия, Италия, Испания, Польша, Франция, Германия, Индия, Нидерланды, Болгария, Латвия, Россия и Великобритания. Стоимость средней суточной дозы (defined daily dose, DDD) для CC, размягчающих каловые массы (вазелиновое масло), колебалась от 2,94 до 3,39 грн. Стоимость DDD для контактных СС колебалась от 0,60 до 3,90 грн: для СС с МНH бисакодил - от 0,60 до 2,82 грн, масло Касторовое - 2,50-5,13 грн, гликозиды Сены - 0,84-3,20 грн, натрия пикосульфат - 1,35-3,90 грн, комбинация натрия пикосульфата с сухим экстрактом листьев Сены - 1,34-1,55 грн. Стоимость DDD для CC, формирующих объем, колебалась от 1,75 до 28,92 грн: СС из семян Подорожника яйцевидного - от 3,58 до 28,92 грн, Ламинарии - 1,75-1,97 грн. Стоимость DDD для осмотических СС колебалась от 2,51 до 112,59 грн: с МHН магния сульфат - от 2,15 до 2,51 грн, стоимость DDD для CС с МНH лактулоза колебалась от 3,75 до 18,74 грн, макрогол - 54,88-127,32 грн, а стоимость комбинации неорганических солей составила 112,59 грн, макрогола - 51,01 грн. Стоимость DDD для CС в клизмах колебалась от 33,39 до 129,03 грн. Стоимость DDD для других СС колебалась от 1,37 до 48,15 грн: глицерина - 3,44-36,49 грн, прукалоприда - 31,72-48,15 грн и различных СС - 1,37-1,49 грн.

Выводы. На фрармацевтическом рынке Украины слабительные средства были представлены $18 \mathrm{MHH}$ и 76 TH; преобладали препараты отечественного производства в соотношении 1,2: 1; стоимость DDD в разрезе минимальной и максимальной стоимости генериков для всех, представленных в этом исследовании СС, колебалась от 0,60 до 129,03 грн.

Ключевые слова: запор; слабительные лекарственные средства; стоимость средней суточной дозы; ATC/DDD-методология

Constipation is a chronic problem for many people in the world. Treatment of constipation is complex and requires the use of laxatives (L) [1-3]. It is very important to study the diversity of the pharmaceutical market of $L$ by manufacturers, international nonproprietary names (INN), trade names (TN), and prices. Thus, to simplify the choice of a laxative by patients, pharmacists and doctors the study of the pharmaceutical market of L is of current interest [4]. In works of V. Iakovenko (2011), K. Shchokina (2007) the results of marketing analysis of $L$ and peculiarities of pharmacotherapy of constipation were given. But this study complements and deepens the previous studies of the problem in Ukraine [4-7].
The aim of the study was to analyze the pharmaceutical market of L in Ukraine.

\section{Materials and Methods}

Data of ATC/DDD-indexes of the WHO Center on methodology of statistical studies of drugs, doses for L recommended by the manufacturer, data on the average retail price of medicines in Ukraine in August 2016 were used in the study. The methods of research were frequency analysis and ATC/DDD-methodology providing the study of the cost of the defined daily dose (DDD) [8]. DDD was determined according to the WHO data. DDDs of L that were not determined by the $\mathrm{WHO}$ were calculated as the average dose recommended by the manufacturer. 


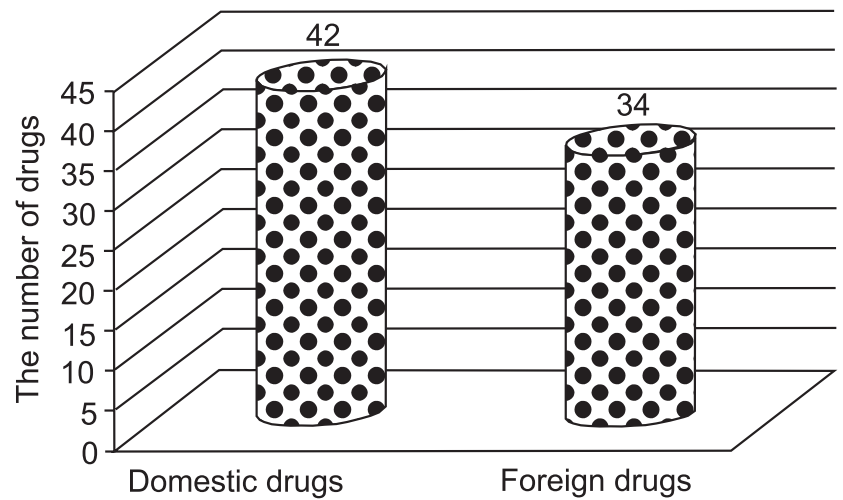

Fig. 1. The ratio of domestic and foreign manufacturers of laxatives at the pharmaceutical market of Ukraine in 2016.

\section{Results and Discussion}

The frequency analysis of the presence of $\mathrm{L}$ at the pharmaceutical market of Ukraine by INN and TN, manufacturing countries in 2016 was performed on the basis of data of "Apteka" (Pharmacy) weekly journal. The weighted average retail value for $\mathrm{L}$ in Ukraine was calculated as of August, 2016.

As the result of the structural analysis of the ATC classification and the presence of $\mathrm{L}$ at the pharmaceutical market of Ukraine it was found that the following drugs of group A06A were available to treat constipation: softeners (emollients), contact L, bulk-forming L, osmotically acting L, L in enemas and other drugs.

The frequency analysis showed that there were 18 INN and $76 \mathrm{TN}$ of $\mathrm{L}$ at the pharmaceutical market of Ukraine in 2016; among them domestic drugs were $55 \%$, and foreign drugs $-45 \%$ (Fig. 1).

Laxatives were supplied in Ukraine by such manufacturing countries as Portugal, Italy, Spain, Poland, France, Germany, India, Netherlands, Bulgaria, Latvia, Russian Federation and United Kingdom (Fig. 2).

The group of softeners (emollients) (A06A A) was represented with Vaseline oil at the pharmaceutical market of Ukraine in 2016. The recommended DDD was 15

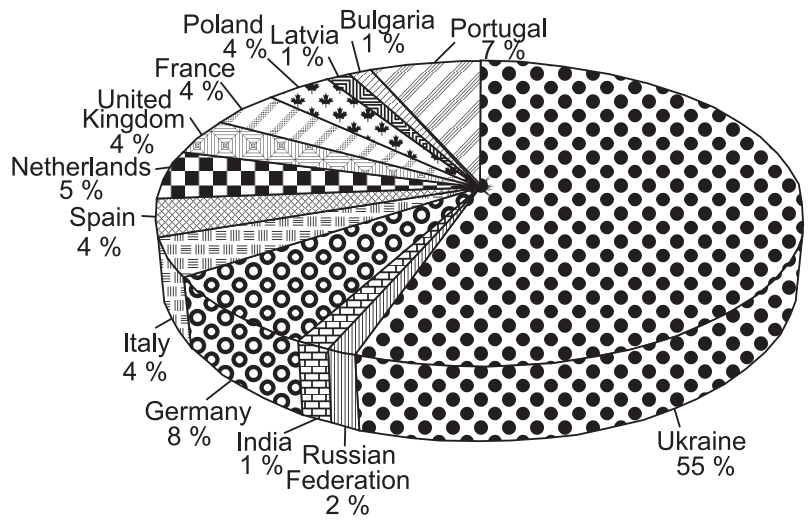

Fig. 2. The ratio of manufacturing countries of laxatives at the pharmaceutical market of Ukraine in 2016.

Table 1

The group of softeners (emollients)

\begin{tabular}{|c|c|c|c|c|}
\hline INN & $\begin{array}{c}\text { DDD, } \\
\mathrm{ml}\end{array}$ & $\mathrm{TN}$ & $\begin{array}{c}\text { Cost per } \\
\text { a pack, } \\
\text { UAH }\end{array}$ & $\begin{array}{l}\text { Cost of } \\
\text { DDD, } \\
\text { UAH }\end{array}$ \\
\hline \multirow{5}{*}{$\begin{array}{l}\text { Vaseline } \\
\text { oil }\end{array}$} & \multirow{5}{*}{15} & $\begin{array}{l}\text { Vaseline oil, } 50 \mathrm{ml} \\
\text { vial, PJSC Fitofarm } \\
\text { (Ukraine, Artemovsk) }\end{array}$ & 9.90 & 2.94 \\
\hline & & $\begin{array}{l}\text { Vaseline oil, } 50 \text { ml } \\
\text { vial, PJSC FF "Viola" } \\
\text { (Ukraine, Zaporizhia) }\end{array}$ & 9.46 & 2.84 \\
\hline & & $\begin{array}{l}\text { Vaseline oil, } 25 \text { ml } \\
\text { vial, PJSC FF “Viola” } \\
\text { (Ukraine, Zaporizhia) }\end{array}$ & 4.45 & 2.67 \\
\hline & & $\begin{array}{l}\text { Vaseline oil, } 25 \mathrm{ml} \\
\text { vial, PJSC Fitofarm } \\
\text { (Ukraine, Artemovsk) }\end{array}$ & 5.85 & 3.51 \\
\hline & & $\begin{array}{l}\text { Vaseline oil, } 50 \mathrm{ml} \\
\text { vial, Farmakom Ltd } \\
\text { (Ukraine, Kharkiv) }\end{array}$ & 11.29 & 3.39 \\
\hline
\end{tabular}

$\mathrm{ml}$. The cost of DDD for Vaseline oil ranged from 2.94 to $3.39 \mathrm{UAH}$ (Tab. 1).

Table 2

The group of contact L

\begin{tabular}{|c|c|c|c|c|}
\hline INN & $\begin{array}{c}\mathrm{DDD}, \\
\mathrm{mg}\end{array}$ & TN & $\begin{array}{c}\text { Cost per } \\
\text { a pack, } \\
\text { UAH }\end{array}$ & $\begin{array}{l}\text { Cost of } \\
\text { DDD, } \\
\text { UAH }\end{array}$ \\
\hline 1 & 2 & 3 & 4 & 5 \\
\hline \multirow{10}{*}{ Bisacodyl } & \multirow{10}{*}{10} & Bisacodyl, dragee, 5 mg, No. 30, Meda Pharma (Germany) & 9.06 & 0.60 \\
\hline & & Bisacodyl-Darnytsia, tbl., 0.005 g, No. 10, Darnytsia ( Ukraine, Kyiv ) & 3.14 & 0.63 \\
\hline & & Bisacodyl, tbl., 5 mg, No. 30, Balkanfarma-Dupnitsa (Bulgaria) & 10.12 & 0.67 \\
\hline & & Bisacodyl-Darnytsia, tbl., 0.005 g, No. 30, Darnytsia (Ukraine, Kyiv) & 10.04 & 0.67 \\
\hline & & $\begin{array}{l}\text { Bisacodyl-Farmeks, supp. rect., } 10 \text { mg, No. 10, Farmeks Group (Ukraine, } \\
\text { Boryspil) }\end{array}$ & 7.35 & 0.74 \\
\hline & & Bisacodyl, supp. rect., 0.01 g, No. 10, Monfarm (Ukraine, Monastyrysche) & 7.86 & 0.77 \\
\hline & & Bisacodyl Grindeks, tbl., 5 mg, No. 40, Grindeks (Latvia) & 16.90 & 0.85 \\
\hline & & Bisacodyl, supp. rect., 0.01 g, No. 10, Lekhim-Kharkiv (Ukraine, Kharkiv) & 9.72 & 0.97 \\
\hline & & $\begin{array}{l}\text { Bisacodyl-Nizhpharm, supp. rect. } 10 \text { mg, No. 10, Nizhpharm } \\
\text { (Russia, Nizhny Novgorod) }\end{array}$ & 24.52 & 2.52 \\
\hline & & Bisacodyl supp. rect., 10 mg, No. 10, GlaxoSmithKline Export (UK) & 28.23 & 2.82 \\
\hline
\end{tabular}


Continuation of Table 2

\begin{tabular}{|c|c|c|c|c|}
\hline 1 & 2 & 3 & 4 & 5 \\
\hline \multirow{9}{*}{ Castor oil } & \multirow{9}{*}{20} & Castor oil, 100 g, PJSC FF “Viola” (Ukraine, Zaporizhia) & 12.50 & 2.50 \\
\hline & & Castor oil, $100 \mathrm{~g}$, PJSC Fitofarm (Ukraine, Artemovsk) & 12.62 & 2.52 \\
\hline & & Castor oil, 30 ml, Lubnyfarm (Ukraine, Lubny) & 5.36 & 3.57 \\
\hline & & Castor oil, 100 ml, Lubnyfarm (Ukraine, Lubny) & 13.54 & 2.71 \\
\hline & & Castor oil, 50 ml, Lubnyfarm (Ukraine, Lubny) & 6.99 & 2.80 \\
\hline & & Castor oil, 30 g, PJSC FF “Viola” (Ukraine, Zaporizhia) & 5.77 & 3.85 \\
\hline & & Castor oil, 30 g, PJSC Fitofarm (Ukraine, Artemovsk) & 5.79 & 3.86 \\
\hline & & Castor oil, 50 g PJSC FF "Viola” (Ukraine, Zaporizhia) & 7.57 & 3.03 \\
\hline & & Castor oil, 50 ml, No. 1, Galychpharm (Ukraine, Lviv) & 12.83 & 5.13 \\
\hline \multirow{5}{*}{ Senna glycosides } & \multirow{4}{*}{$500^{*}$} & Senalax, tbl., $0.5 \mathrm{~g}$ No. 500 Osiris (Ukraine, Dnipro) & 421.98 & 0.84 \\
\hline & & Senna, caps., 250 mg, No. 30, Pharmacy 283 (Ukraine, Volchansk) & 29.22 & 1.95 \\
\hline & & Senna-forte, caps., 250 mg, No. 30, Pharmacy 283 (Ukraine, Volchansk) & 34.97 & 2.33 \\
\hline & & Senna extract, tbl., 250 mg, No. 10 Pharmacy 283 (Ukraine, Volchansk) & 16.00 & 3.20 \\
\hline & $8.39^{*}$ & Regulax fruit, cubes No. 6, Krevel Moyzelbah (Germany) & 72.74 & 12.12 \\
\hline \multirow{7}{*}{ Sodium picosulfate } & \multirow{5}{*}{7.5} & Picolax, drops, 30 ml, $0.75 \%$, "Farmak” (Ukraine) & 40.39 & 1.35 \\
\hline & & Guttalax, drops, $7.5 \mathrm{mg} / \mathrm{ml}, 30 \mathrm{ml}$, Boehringer Ingelheim (Germany) & 107.45 & 3.58 \\
\hline & & Picolax, drops, $15 \mathrm{ml}$, $0.75 \%$, "Farmak" (Ukraine) & 26.24 & 1.75 \\
\hline & & $\begin{array}{l}\text { Regulax picosulfate, drops, } 20 \mathrm{ml} \text { vial, Krevel Moyzelbah GmbH } \\
\text { (Germany) }\end{array}$ & 77.55 & 3.88 \\
\hline & & Guttalax, drops, $7.5 \mathrm{mg} / \mathrm{ml}, 15 \mathrm{ml}$, Boehringer Ingelheim (Germany) & 58.45 & 3.90 \\
\hline & \multirow{2}{*}{$5^{*}$} & Picolax, tbl., 5 mg, No. 10, “Farmak" (Ukraine) & 14.50 & 1.45 \\
\hline & & Picolax, tbl., 7.5 mg, No. 10, "Farmak" (Ukraine) & 21.99 & 2.20 \\
\hline \multirow{2}{*}{$\begin{array}{l}\text { Combination of } \\
\text { sodium picosulfate } \\
\text { and a dry extract of } \\
\text { senna leaves, } 10 \mathrm{mg}\end{array}$} & \multirow{2}{*}{$7.5 / 10^{*}$} & $\begin{array}{l}\text { Picosen, oral drops, } 15 \mathrm{ml} \text {, "Pharmaceutical Factory” (Ukraine, } \\
\text { Zhytomyr) }\end{array}$ & 23.21 & 1.55 \\
\hline & & $\begin{array}{l}\text { Picosen, oral drops, } 25 \text { ml, “Pharmaceutical Factory” (Ukraine, } \\
\text { Zhytomyr) }\end{array}$ & 33.53 & 1.34 \\
\hline
\end{tabular}

Notes: * - DDDs of $L$ that were not determined by the WHO.

The group of contact L (A06A B) consisted of 5 INN and $33 \mathrm{TN}$ at the pharmaceutical market of Ukraine in 2016 (Tab. 2).

The cost of DDD for contact L was from 0.60 to 3.90 UAH: for bisacodyl - from 0.60 to $2.82 \mathrm{UAH}$, for castor oil - 2.50-5.13 UAH, for senna glycosides - 0.843.20 UAH, for sodium picosulfate - 1.35-3.90 UAH, for combination of sodium picosulfate with a dry extract of senna leaves - 1.34-1.55 UAH.

The group of bulk-forming L (A06A C) consisted of 2 INN and $4 \mathrm{TN}$ at the pharmaceutical market of Ukraine in 2016 (Tab. 3).

The cost of DDD of bulk-forming L ranged from 1.75 to $129.03 \mathrm{UAH}$ : for L with Plantago ovata seeds ranged from 3.58 to 28.92 UAH, for laminaria - 1.75-1.97 UAH.

The group of osmotically acting L (A06A D) consisted of $5 \mathrm{INN}$ and $13 \mathrm{TN}$ at the pharmaceutical market of Ukraine in 2016 (Tab. 4).

The cost of DDD for osmotically acting L varied from 2.51 to $112.59 \mathrm{UAH}$ : for magnesium sulfate -2.15 2.51 UAH. and the cost for combination of inorganic salts - 112.59 UAH, for macrogol - 51.01 UAH, for lactulose - 3.75-18.74 UAH, for combinations with macrogol - 54,88-127,32 UAH.

The group of $\mathrm{L}$ in enemas (A06A G) was represented with docusate sodium and combinations of sodium di- hydrogen phosphate dihydrate and sodium hydrogen phosphate dodecahydrate (Tab. 5).

The cost of DDD for $\mathrm{L}$ in enemas varied from 33.39 to 129.03 UAH. The group of other L (A06A X) was represented with glycerol, prucalopride and various LM (Tab. 6).

Table 3

The group of bulk-forming L

\begin{tabular}{|c|c|l|c|c|}
\hline \multicolumn{1}{|c|}{ INN } & $\begin{array}{c}\text { DDD, } \\
\mathrm{g}\end{array}$ & \multicolumn{1}{|c|}{ TN } & $\begin{array}{c}\text { Cost per } \\
\text { a pack, } \\
\text { UAH }\end{array}$ & $\begin{array}{c}\text { Cost of } \\
\text { DDD, } \\
\text { UAH }\end{array}$ \\
\hline $\begin{array}{l}\text { Drugs with } \\
\text { Plantago } \\
\text { ovata } \\
\text { seeds }\end{array}$ & $1^{*}$ & $\begin{array}{l}\text { Defenorm, caps, } \\
\text { No. 30, "KVZ" } \\
\text { (Ukraine, Kyiv) }\end{array}$ & 53.79 & 3.58 \\
\cline { 2 - 5 } Other L & $5^{*}$ & $\begin{array}{l}\text { Mucofalk orange, } \\
\text { 5 g pack, No. 20, } \\
\text { Dr. Falk Pharma } \\
\text { (Germany) }\end{array}$ & 192.77 & 28.92 \\
\cline { 2 - 5 } & & $\begin{array}{l}\text { Laminaria, } \\
\text { 150 g, "Liktravy" } \\
\text { (Ukraine) }\end{array}$ & 52.37 & 1.75 \\
\hline $\begin{array}{l}\text { Laminaria, } \\
\text { 75 g, “Liktravy" } \\
\text { (Ukraine) }\end{array}$ & 29.50 & 1.97 \\
\hline
\end{tabular}

Notes: * DDDs of $L$ that were not determined by the WHO. 
The group of osmotically acting L

\begin{tabular}{|c|c|c|c|c|}
\hline INN & DDD, $g$ & TN & $\begin{array}{c}\text { Cost per } \\
\text { a pack, } \\
\text { UAH }\end{array}$ & $\begin{array}{l}\text { Cost of } \\
\text { DDD, } \\
\text { UAH }\end{array}$ \\
\hline \multirow{3}{*}{ Magnesium sulfate } & \multirow{3}{*}{7} & $\begin{array}{l}\text { Magnesium sulfate, powder, } 25 \text { g container, PJSC FF } \\
\text { "Viola" (Ukraine, Zaporizhia) }\end{array}$ & 7.67 & 2.15 \\
\hline & & $\begin{array}{l}\begin{array}{l}\text { Magnesium sulfate, powder, } 25 \mathrm{~g} \text { pack, PJSC FF "Viola" } \\
\text { (Ukraine, Zaporizhia) }\end{array} \\
\end{array}$ & 7.83 & 2.19 \\
\hline & & \begin{tabular}{|l|} 
Magnesium sulfate, powder for solution for oral use, \\
$25 \mathrm{~g}$ container, Istok-Plus (Ukraine, Zaporizhia) \\
\end{tabular} & 8.95 & 2.51 \\
\hline $\begin{array}{l}\text { Combinations of } \\
\text { inorganic salts (disodium } \\
\text { hydrogen phosphate } \\
\text { dodecahydrate/sodium } \\
\text { dihydrogen phosphate } \\
\text { dihydrate }\end{array}$ & $5.76 / 3^{*}$ & $\begin{array}{l}\text { Fleet Phospho-soda, } 45 \mathrm{ml} \text { for oral use, No. 2, Casen- } \\
\text { Fleet Laboratories (Spain) }\end{array}$ & 225.17 & 112.59 \\
\hline \multirow{6}{*}{ Lactulose } & \multirow{6}{*}{6.7} & Normase, syrup, $200 \mathrm{ml},(15 \mathrm{ml} / 10 \mathrm{~g})$, Molten (Italy) & 74.92 & 3.75 \\
\hline & & $\begin{array}{l}\text { Duphalac, syrup, } 667 \mathrm{mg} / \mathrm{ml} \text { vial, } 1000 \mathrm{ml} \text {, Abbott } \\
\text { Healthcare Products (Netherlands) }\end{array}$ & 521.97 & 5.30 \\
\hline & & $\begin{array}{l}\text { Duphalac, syrup, } 667 \mathrm{mg} / \mathrm{ml} \text { vial, } 200 \mathrm{ml} \text {, Abbott } \\
\text { Healthcare Products (Netherlands) }\end{array}$ & 147.16 & 7.36 \\
\hline & & $\begin{array}{l}\text { Medulak syrup, } 667 \mathrm{mg} / \mathrm{ml}, 180 \mathrm{ml} \text { bottles, No. } 1 \text {, } \\
\text { World Medicine Ltd (Great-Britain) }\end{array}$ & 134.98 & 7.50 \\
\hline & & $\begin{array}{l}\text { Duphalac, syrup, } 667 \mathrm{mg} / \mathrm{ml} \text { vial, } 500 \mathrm{ml} \text {, Abbott } \\
\text { Healthcare Products (Netherlands) }\end{array}$ & 290.92 & 5.82 \\
\hline & & $\begin{array}{l}\text { Duphalac, syrup } 667 \mathrm{mg} / \mathrm{ml} \text { vial, } 15 \mathrm{ml} \text {, Abbott } \\
\text { Healthcare Products (Netherlands) }\end{array}$ & 281.80 & 18.74 \\
\hline Macrogol & 64 & $\begin{array}{l}\text { Diagnol powder for solution for oral use, } 64 \text { g, No. 4, } \\
\text { "Farmak" (Ukraine) }\end{array}$ & 204.05 & 51.01 \\
\hline \multirow{2}{*}{$\begin{array}{l}\text { Combinations of macrogol } \\
\text { with sodium chloride and } \\
\text { potassium chloride }\end{array}$} & \multirow{2}{*}{$100 / 2.69 / 1.01^{*}$} & $\begin{array}{l}\text { Moviprep, powder for solution for oral use in sachet A } \\
\text { No.1, and B No.1, Norgine Limited, UK }\end{array}$ & 254.64 & 127.32 \\
\hline & & $\begin{array}{l}\text { Endofalk powder for solution for oral use, No. 6, } \\
\text { Dr. Falk Pharma GmbH (Germany) }\end{array}$ & 329.27 & 54.88 \\
\hline
\end{tabular}

Notes: ${ }^{*}-$ DDDs of $L$ that were not determined by the WHO.

Table 5

The group of $\mathrm{L}$ in enemas

\begin{tabular}{|l|c|l|c|c|}
\hline \multicolumn{1}{|c|}{ INN } & $\begin{array}{l}\text { DDD, } \\
\mathrm{g} / \mathrm{ml}\end{array}$ & \multicolumn{1}{|c|}{ TN } & $\begin{array}{c}\text { Cost per } \\
\text { a pack, } \\
\text { UAH }\end{array}$ & $\begin{array}{c}\text { Cost of } \\
\text { DDD, } \\
\text { UAH }\end{array}$ \\
\hline Docusate sodium & $10 \mathrm{~g}^{*}$ & $\begin{array}{l}\text { Norgalax, rectal gel, 10 g, No. 6, } \\
\text { Norgine Pharma, France }\end{array}$ & 200.31 & 33.39 \\
\hline \multirow{2}{*}{$\begin{array}{l}\text { Combinations of sodium } \\
\text { dihydrogen phosphate } \\
\text { dihydrate and sodium hydrogen } \\
\text { phosphate dodecahydrate }\end{array}$} & $60 \mathrm{ml}^{*}$ & $\begin{array}{l}\text { Fleet Ready-To-Use enema, rectal solution, 133 ml } \\
\text { bottle, No. 1, Lab. Casen-Fleet (Spain) }\end{array}$ & 91.59 & 91.59 \\
\cline { 2 - 5 } & $130 \mathrm{ml}^{*}$ & $\begin{array}{l}\text { Enema, cleansing rectal solution 3.22g/100ml + } \\
13.9 \mathrm{~g} / 100 \mathrm{ml}, 150 \mathrm{ml} \text { vial, Laboratorium Galenowe } \\
\text { Olsztyn, Poland }\end{array}$ & 102.23 & 102.23 \\
\cline { 2 - 5 } & $130 \mathrm{ml}^{*}$ & $\begin{array}{l}\text { Normacol enema for adults, 130 ml, } \\
\text { Norgine Pharma, France }\end{array}$ & 128.69 & 128.69 \\
\cline { 2 - 5 } & $150 \mathrm{ml}^{*}$ & $\begin{array}{l}\text { Normacol enema for adults, 60 ml, } \\
\text { Norgine Pharma, France }\end{array}$ & 129.03 & 129.03 \\
\hline
\end{tabular}

Notes: * DDDs of $L$ that were not determined by the WHO. 
The group of other L

\begin{tabular}{|c|c|c|c|c|}
\hline INN & $\begin{array}{l}\mathrm{DDD}, \\
\mathrm{mg} / \mathrm{ml} / \mathrm{g}\end{array}$ & TN & \begin{tabular}{|c|} 
Cost per \\
a pack, \\
UAH \\
\end{tabular} & $\begin{array}{l}\text { Cost of } \\
\text { DDD, } \\
\text { UAH }\end{array}$ \\
\hline \multirow{11}{*}{ Glycerol } & $1000 \mathrm{mg}$ & $\begin{array}{l}\text { Glycerol Nosta, } 1000 \text { mg, sup. rect., No. } 12(6 \times 2) \text {, Laboratórios Basi } \\
\text { Industria Farmaceutica (Portugal) }\end{array}$ & 41.36 & 3.44 \\
\hline & $1405 \mathrm{mg}$ & $\begin{array}{l}\text { Glycerin sup. “Farmina” for children, } 1.405 \text { mg, No. 12, strip, } \\
\text { Farmholding (Kyiv, Ukraine) }\end{array}$ & 71.49 & 5.95 \\
\hline & $1000 \mathrm{mg}$ & $\begin{array}{l}\text { Glycerol Euro, sup. rect., } 1000 \text { mg, No. 12, }(6 \times 2) \text { blister, Laboratórios Basi } \\
\text { Industria Farmaceutica (Portugal) }\end{array}$ & 75.32 & 6.28 \\
\hline & $2000 \mathrm{mg}$ & $\begin{array}{l}\text { Glycerol Euro, sup. rect., } 2000 \text { mg, No. 12, }(6 \times 2) \text { blister, Laboratórios Basi } \\
\text { Industria Farmaceutica (Portugal) }\end{array}$ & 87.36 & 7.28 \\
\hline & $2100 \mathrm{mg}$ & $\begin{array}{l}\text { Glycerin sup. “Farmina” for children, } 2.1 \text { mg, No. 12, strip, } \\
\text { Farmholding (Kyiv, Ukraine) }\end{array}$ & 91.79 & 7.65 \\
\hline & $1000 \mathrm{mg}$ & $\begin{array}{l}\text { Glycerol Euro, sup. rect., } 1000 \text { mg, No. 6, blister, Laboratórios Basi } \\
\text { Industria Farmaceutica (Portugal) }\end{array}$ & 46.16 & 7.69 \\
\hline & $1500 \mathrm{mg}$ & Glycerin rect. sup. "Farmina”, 1.5 g, No. 5, blist, Farmina Ltd (Poland) & 43.01 & 8.60 \\
\hline & $2000 \mathrm{mg}$ & $\begin{array}{l}\text { Glycerol Euro, sup.rect., } 2000 \text { mg, No. 6, blister Laboratórios Basi Industria } \\
\text { Farmaceutica (Portugal) }\end{array}$ & 53.82 & 8.97 \\
\hline & $750 \mathrm{mg}$ & Glycerin rect. sup. “Farmina”, 0.75 g, No. 5, blist, Farmina Ltd (Poland) & 50.91 & 10.18 \\
\hline & $3.28 \mathrm{ml}^{*}$ & $\begin{array}{l}\text { Glycerin microenemas "Paidolax" for children, } 3.28 \mathrm{ml} \text {, applicator, } 4 \mathrm{ml} \text {, } \\
\text { No. 4, Casen Recordati (Spain) }\end{array}$ & 135.90 & 33.98 \\
\hline & $6.14 \mathrm{ml}^{*}$ & $\begin{array}{l}\text { Glycerin microenemas "Adulax" for adult, } 6.14 \text { ml, No. 4, } \\
\text { Casen Recordati (Spain) }\end{array}$ & 145.97 & 36.49 \\
\hline \multirow{2}{*}{ Prucalopride } & $2 \mathrm{mg}$ & Resolor, tbl., 1 mg, No. $28(7 \times 4)$ blister, Janssen-Cilag (Italy) & 674.07 & 48.15 \\
\hline & $2 \mathrm{mg}$ & Resolor, tbl., 2 mg, No. $28(7 \times 4)$ blister, Janssen-Cilag (Italy) & 888.20 & 31.72 \\
\hline \multirow{2}{*}{$\begin{array}{l}\text { Various } \\
\text { laxatives }\end{array}$} & 2 packs* & Herbal laxative tea, 2 g pack, No. 20, "Liktravy” (Ukraine, Zhytomyr) & 13.71 & 1.37 \\
\hline & $10 \mathrm{~g}^{*}$ & Herbal laxative tea, 75 g pack, No. 1, "Liktravy” (Ukraine, Zhytomyr) & 14.90 & 1.49 \\
\hline
\end{tabular}

Notes: * DDDs of $L$ that were not determined by the WHO.

The cost of DDD for other drugs for treatment of constipation was from 1.37 to $48.15 \mathrm{UAH}$ : for glycerol 3.44-36.49 UAH, for prucalopride - 31.72-48.15 UAH, for others - 1.37-1.49 UAH.

Therefore, the cost of DDD for L in the context of the minimum and maximum cost of generics ranged from 0.60 to $129.03 \mathrm{UAH}$.

\section{CONCLUSIONS}

1. As the result of the marketing analysis of laxatives it has been found that there were $18 \mathrm{INN}$ and $76 \mathrm{TN}$ of laxatives at the pharmaceutical market of Ukraine in 2016.

2. At the pharmaceutical market of Ukraine drugs of domestic manufacture prevailed, the ratio between domestic and foreign drugs was $1.2: 1$. Laxatives were supplied by such manufacturing countries as Portugal, Italy, Spain, Poland, France, Germany, India, Netherlands, Bulgaria, Latvia, Russian Federation and United Kingdom.
3. The cost of DDD for softeners ranged from 2.94 to $3.39 \mathrm{UAH}$; for contact $\mathrm{L}$ was from 0.60 to $3.90 \mathrm{UAH}$; for bulk-forming L ranged from 1.75 to $129.03 \mathrm{UAH}$; for osmotically acting L varied from 2.51 to $112.59 \mathrm{UAH}$; and the cost for combination of inorganic salts - 112.59 UAH, for macrogol - 51.01 UAH, for lactulose - 3.75-18.74 UAH, for combinations with macrogol - 54.88-127.32 UAH. The cost of DDD for L in enemas varied from 33.39 to 129.03 UAH, and for other drugs for treatment of constipation was from 1.37 to $48.15 \mathrm{UAH}$.

4. The cost of DDD for laxatives in the context of the minimum and maximum cost of generics ranged from 0.60 to $129.03 \mathrm{UAH}$.

Prospects of further research. Based on the data obtained it will be possible to identify cost-effectiveness advantages of the drugs studied.

Conflicts of Interest: authors have no conflict of interest to declare.

\section{REFERENCES}

1. Constipation : a global perspective [Internet] // World Gastroenterology Organisation Global Guidelines. - Available at : http://www. worldgastroenterology.org/assets/export/userfiles/05_constipation.pdf.

2. Лещишин, І. М. Закрепи: глобальна перспектива (Рекомендації Світової організації гастроентерологів, листопад 2010 року) / І. М. Лещишин, О. І. Охоцька, Л. Ю. Маркулан // Хірургія України. - 2013. - № 3. - С. 7-13.

3. Liu, L. W. C. Chronic constipation: current treatment options / L. W. C. Liu // Can. J. Gastroenterol. - 2011. - Vol. 25, Issue suppl. b. P. 22B-8B. doi : 10.1155/2011/360463. 
4. Яковенко, В. К. Сучасний стан фармацевтичного ринку проносних лікарських засобів в Україні / В. К. Яковенко // Управління, економіка та забезпечення якості в фармації. - 2011. - № 2 (16). - С. 48-53.

5. Щекина, Е. Г. Современные подходы к коррекции запоров / Е. Г. Щекина // Провизор. - 2007. - № 17. - С. 15-18.

6. Ford, A. C. Effect of laxatives and pharmacological therapies in chronic idiopathic constipation: systematic review and meta-analysis / A. C. Ford, N. C. Suares // Gut. - 2011. - Vol. 60, Issue 2. - P. 209-218. doi : 10.1136/gut.2010.227132.

7. Lactulose : an effective preventive and therapeutic option for ischemic stroke by production of hydrogen / X. Chen, X. Zhai, Z. Kang, X. Sun // Med. Gas Res. - 2012. - Vol. 2. - P. 3. doi : 10.1186/2045-9912-2-3.

8. WHOCC-ATC/DDD Index [Internet]. - Available at : http://www.whocc.no/atc_ddd_index.

\section{REFERENCES}

1. Constipation: a global perspective. World Gastroenterology Organisation Global Guidelines. Available at: http://www.worldgastroenterology.org/assets/export/userfiles/05_constipation.pdf

2. Leshchyshyn, I. M., Okhotska, A. I., Markulan, L. Y. (2013). Khirurhiia Ukrainy - Surgery of Ukraine, 3, 7-13.

3. Liu, L. W. C. (2011). Chronic Constipation: Current Treatment Options. Canadian Journal of Gastroenterology, 25 (suppl b), $22 \mathrm{~B}-28 \mathrm{~B}$. doi: 10.1155/2011/360463

4. Yakovenko, V. K. (2011). Current state of the pharmaceutical market laxatives medicines in Ukraine. Management, economics and quality assurance in pharmacy, 2 (16), 48-53.

5. Schokina, E. G. (2007). Provizor, 17, 15-18.

6. Ford, A. C., Suares, N. C. (2011). Effect of laxatives and pharmacological therapies in chronic idiopathic constipation: systematic review and meta-analysis. Gut, 60 (2), 209-218. doi: 10.1136/gut.2010.227132

7. Chen, X., Zhai, X., Kang, Z., Sun, X. (2012). Lactulose: an effective preventive and therapeutic option for ischemic stroke by production of hydrogen. Medical Gas Research, 2 (1), 3. doi: 10.1186/2045-9912-2-3

8. WHOCC-ATC/DDD Index. Available at: http: // www.whocc.no/atc_ddd_index

Information about authors:

Ivko T., Candidate of Pharmacy (Ph.D.), teaching assistant of the Pharmacy Department, National Pirogov Memorial Medical University. E-mail: ivkot@e-mail.ua Germanyuk T., Doctor of Medicine, professor of the Pharmacy Department, National Pirogov Memorial Medical University

Bobrytska L., Doctor of Pharmacy, assistant professor of the Department of Industrial Technology of Drugs, National University of Pharmacy

Відомості про авторів:

Івко Т. I., канд. фарм. наук, асистент кафедри фармації, Вінницький національний медичний університет імені М. I. Пирогова. E-mail: ivkot@e-mail.ua

Германюк Т. А., д-р мед. наук, професор кафедри фармації, Вінницький національний медичний університет імені М. І. Пирогова

Бобрицька Л. О., д-р фарм. наук, доцент кафедри заводської технології ліків, Національний фармацевтичний університет

Сведения об авторах:

Ивко Т. И., канд. фарм. наук, ассистент кафедры фармации, Винницкий национальный медицинский университет имени Н. И. Пирогова.

E-mail: ivkot@e-mail.ua

Германюк Т. А., д-р мед. наук, профессор кафедры фармации, Винницкий национальный медицинский университет имени Н. И. Пирогова

Бобрицкая Л. А., д-р фарм. наук, доцент кафедры заводской технологии лекарств, Национальный фармацевтический университет 